\title{
Marketization of Higher Education: A European Perspective
}

\author{
Amedeo Toderoiu ${ }^{1}$ \\ ${ }^{1}$ Faculty of Humanities, Technical University of Cluj-Napoca, Cluj-Napoca, Romania \\ Correspondence: Amedeo Toderoiu, Faculty of Humanities, Technical University of Cluj-Napoca, Cluj-Napoca, \\ Romania.
}

Received: April 2, 2021

doi:10.5430/irhe.v6n1p36
Accepted: April 20, 2021

URL: https://doi.org/10.5430/irhe.v6n1p36

\begin{abstract}
This paper introduces the research and understanding of European higher education experts on the newly raised higher education marketization. Their point of view is that higher education marketization is by introducing market mechanism and making operation with market characteristics of higher education. Higher education market is a "quasi market". Higher education institutions under the condition of marketization are "a hybrid institution", in which students are the biggest consumers. Colleges and universities are encouraged to introduce accounting systems of enterprises in marketization competition, etc.
\end{abstract}

Keywords: marketization, higher education, European perspective, globalization

\section{Introduction}

"Marketization" is one of the most frequent and popular terms in European higher education literature in the last decade. Marketization of higher education has received unprecedented attention, debate and research. Concepts such as massification, decentralization, privatization, and deregulation spring up accordingly accompanying marketization. These concepts have evolved and become a powerful trend in the development of European higher education, which has brought European higher education into the 21st century with this distinctive feature.

Globalization is one of the most important contexts to understand the reform of contemporary higher education. Since the 1980s, higher education in the world has generally been in short supply and faced with financial pressure. The introduction of quasi-market mechanism to solve the problem has become a common choice. The information-based global economy is an economic competition based on "information and knowledge" in the world market system. It encourages nation-state governments to become globally competitive governments. The close global linkage makes the higher education reform of various countries show certain convergence and similarity, and mutual imitation and reference become a symbol of the world higher education reform. Under the impact of globalization, the government of a national state is forced to become a global competitive government, and has to restructure and reposition its own role. The government has changed its traditional role as a service provider and is committed to mobilizing and guiding market and private forces to participate in the provision of social welfare, including education. Its own role gradually changed to the coordinator of social activities, monitor and control of service quality.

\section{Background}

For quite a long period before the 1980s, the tradition of Higher education in Europe was centralized or government-led. Higher education was a social public service, and higher education institutions were non-profit organizations. As the provider and purchaser of higher education, the government was responsible for the establishment of higher education, the provision of higher education (including private university education later) funds and student tuition fees, the formulation of higher education policies and the determination of professional settings and enrollment numbers. Higher education institutions were engaged in non-profit undertakings, focusing on teaching, research and service to the community, without much consideration and attention to the benefits of the use of higher education resources, the needs of society and enterprises, and the needs of students. In this case, academic freedom was respected and the classical Humboldt spirit was promoted.

In the 1980s, excessive social welfarism, economic recession and the increase of government fiscal deficit gave birth to Thatcherism. Thatcherism quickly gained popularity among western European governments. Under its influence, the concept of privatization and marketization began to be introduced into many public utility areas, such as public 
transportation, social welfare and safety, health and infrastructure. On the other hand, with the popularization of higher education in the 1960s, the number of students in European institutions of higher learning increased exponentially. The governments were overwhelmed and could not continue, so they sought for ways out of the difficulties. At the same time, with the increase of government investment in higher education, the efficiency of higher education funds, the value of services provided by higher education institutions and social adaptability have been widely concerned and questioned. In addition, governments in most Western European countries have come to realize that the planned and controlled model that was supposed to improve the adaptability, effectiveness and quality of higher education has not been achieved. All these factors directly lead the western European countries to use the university autonomy model to replace the centralized model. In this new model, marketization of higher education is a key concept.

Table 1. The benefits of higher education

\begin{tabular}{|c|c|c|}
\hline & National-State & hdivi \\
\hline Economic & $\begin{array}{ll}> & \text { Economic growth } \\
> & \text { Poverty reduction } \\
> & \text { Sustained income growth } \\
> & \text { Shift to knowledge-based economy } \\
> & \text { Research and innovation systems } \\
> & \text { Foreign direct investment } \\
> & \text { Employee productivity } \\
> & \text { Increased tax revenues } \\
> & \text { Increased consumption } \\
> & \text { Increased labour flexibility } \\
> & \text { Entrepreneurship }\end{array}$ & 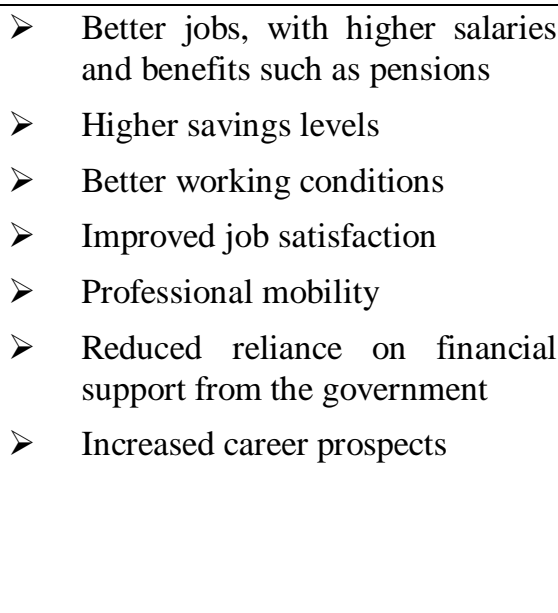 \\
\hline Socia & 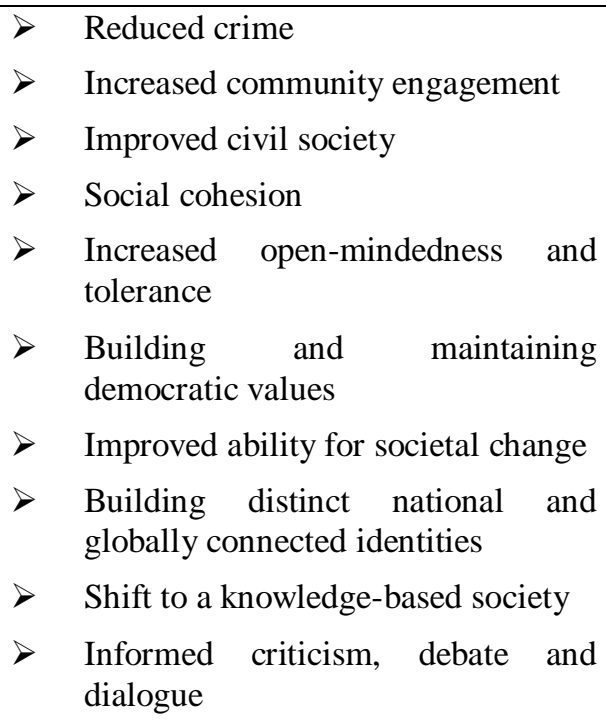 & 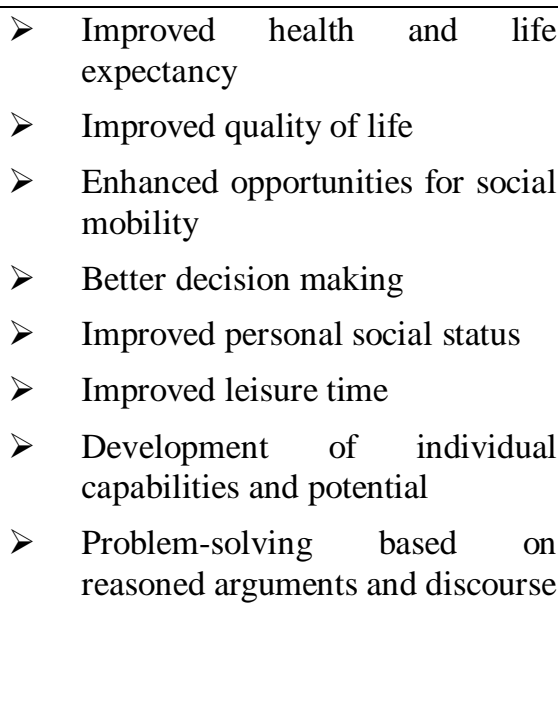 \\
\hline Academic/Educational & $\begin{array}{l}>\quad \begin{array}{l}\text { More better-qualified teachers for } \\
\text { the education system }\end{array} \\
>\quad \begin{array}{l}\text { More avenues for research in the } \\
\text { education system }\end{array} \\
>\quad \begin{array}{l}\text { More international in outlook } \\
>\quad \begin{array}{l}\text { Ability to survive the challenges of } \\
\text { globalization }\end{array}\end{array}\end{array}$ & $\begin{array}{l}>\text { Building up of the total person } \\
>\quad \begin{array}{l}\text { Opportunities for lifelong } \\
\text { learning }\end{array} \\
>\quad \begin{array}{l}\text { Fulfilment of destiny and role in } \\
\text { society }\end{array}\end{array}$ \\
\hline
\end{tabular}




\section{The Concept of Marketization of Higher Education}

The concept of marketization of higher education has been extensively discussed by higher education experts in various European countries. Here are only a few representative views.

It is generally believed that marketization means introducing market mechanism to make higher education marketable. In 1997, the Organization for Economic Cooperation and Development (OECD) defined the marketization of higher education as: "The introduction of market mechanisms into higher education that enable higher education operations to have at least one of the following salient market characteristics: competition, choice, price, decentralized decision making, monetary incentives, etc. It ruled out absolute traditional public ownership and absolute privatization." According to OECD, the marketization of higher education is not absolute privatization or absolute public ownership, but a process of introducing market mechanisms to make higher education institutions more competitive, autonomous and widely adaptable.

Smith D. gives a thought-giving definition, arguing that "marketization is an organizational orientation that places the customers at the center of the decision-making process, and it may trigger a transformation in the culture of higher education." He regards marketization of higher education as a cultural phenomenon, which is the transformation of higher education from one cultural form to another, or it can be regarded as a new reconstruction of higher education culture. The marketization of higher education is to determine the needs of customers and produce qualified products to meet their needs. Higher education institutions must provide high quality services to a wide range of customers and sponsors (students, governments, employers, businesses, alumni, donors, etc.). In this new cultural form, the relationship between higher education institutions and society has become that of providers and demanders (buyers). Hans J. J. Vossensteyn believes that, in a broader sense, the marketization of higher education is a trend towards decentralization, competitiveness enhancement and introduction of business methods in higher education. It involves establishing a more direct link between producers and users, enabling producers to meet the needs of society more effectively and charging towards users and realizing fully privatization.

Jog. Koelman points out that there are three practical forms of marketization in higher education. The first form is college autonomy. The trend of university autonomy leads to market tendency and flexibility. European universities have traditionally enjoyed ample freedom of teaching and research, yet without a modern sense of the market. The classical academic autonomy (freedom) proposed by Humboldt is significantly different from the modern university autonomy, which includes production process and organization problems, and it is precisely the latter so-called process autonomy that is market-oriented. This autonomy gives universities wide latitude to respond quickly to market signals.

The second form is a shift in funding, especially from government funding, from a functional budget to a behavioural target budget. This transformation is consistent with the mainstream of college autonomy, and it opens the way to market orientation and process autonomy, which is manifested as another market characteristic of higher education, namely management doctrine. Process autonomy and management doctrine emphasize output-based and behavior target budget, which greatly weaken the hierarchical relationship between government and university operators, and strengthen the sense of responsibility of university management. As professionals, university managers know how to control and manage all production procedures and processes. They need the flexibility and space to determine the use of resources, rather than the constraints of bureaucratic control. Hierarchies will be replaced by product accountability. Neave and Van Vught analyzed the difference between process control and product control and thought that marketization is the government fading out from process control rather than reducing the control of product. In addition, the marketization of higher education is also reflected in the transformation of higher education institutions' funding from the government directly to relying on demander investment. Marketization requires students to pay part of the training fee, and from the demander's point of view, marketization leads to the formation of consumer authority. Consumer authority means that students are consumers who have the right to discuss the ratio of price to quality and decide whether to buy educational services. The upshot is colleges' incomes depend on consumer choices. This demand dependence not only makes colleges and universities pay attention to cost accounting, but also requires colleges and universities to have a competitive mechanism to provide better education services.

A third form is the formation of a "quasi-market" (more common in the public sector) in which monopolistic government providers are replaced by "competitive independent providers". In order to form a competitive "quasi-market" of higher education, the following three preconditions must be established. (1) An open market structure. Markets should be open to new providers. (2) Sufficient incentive measures. Both consumers and producers must have adequate financial incentives to show their preferences (students and other consumers) and to 
conduct research and teaching more effectively. (3) Information on teaching and research quality. Both consumers and higher education institutions must have easy access to accurate information about the quality of teaching and research.

Table 2. Marketizing higher education

\begin{tabular}{llll}
\hline Model & Internationalization & Trade Flow & Consumption \\
& Flow & & \\
\hline Import Model & Inbound & & \\
& Student/Faculty & Consumer $\rightarrow$ Producer & deficit to domestic \\
& Mobility & & \\
\hline Export Model & Outbound & Producer $\rightarrow$ Consumer & surplus to foreign \\
& Student/Faculty & & \\
& Mobility & & \\
\hline Partnership Model & Joint Policy/Degree & Producer $\rightarrow$ Consumer & commodity chain \\
& Authority & & \\
& Distance/MOOCs & & \\
& S. (2014) & & \\
\hline
\end{tabular}

Source: Olds, K., \& Robertson, S. (2014)

\section{Globalization and Marketization of Higher Education}

How does global economic competition affect national higher education systems and individual universities? That is, what are the specific ways and means by which it affects? For a single organization, in particular, a narrative that is too grand can seem remote and obtuse.

\subsection{Offset and Mitigation Between Globalization and Localization}

The truth is that the wave of globalization is refracted through multiple layers of different institutions at multiple levels, as the word glonacal and what Figure 1 reflects, reshaping the existence environment of various organizations and movers (such as countries, universities, and even individuals) at different levels.

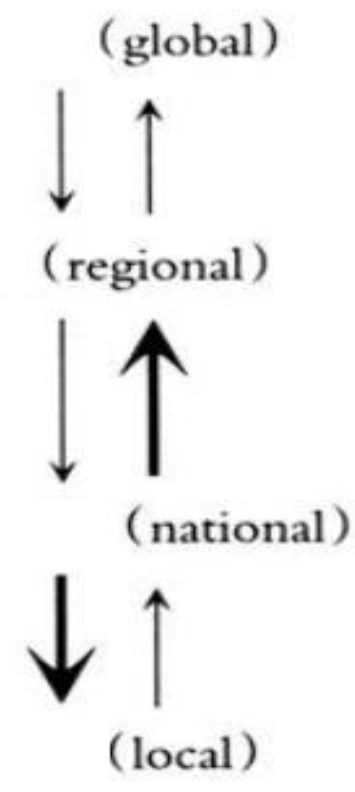

Figure 1. Offset and mitigation between globalization and localization

Note: The direction of arrows indicates the direction of influence, and the size of arrows indicates the strength of influences 
As Shown in Figure 1, globalization is never one-way: globalization and localization, convergence and divergence always work together. The pressures of globalization and the efforts of nation-state governments to defend their independence and legitimacy have been offset and mitigated through regional institutions. For example, the unification of academic system within the European Union (EU), on one hand, reflects the challenge of globalization to the higher education system of nation states. On the other hand, it is a way for European countries to act together to strengthen their influence in the global landscape. Within nation-states and at a more microscopic level, the mechanisms are often similar, and the strategies of smaller organizations (such as universities or even their subunits) responding to globalization can also be analyzed based on the distribution of control at different levels within the higher education system. But of all these levels, the nation-state remains the most important. Whether compared with various loose international organizations or associations, or compared with its subordinate organizations at all levels, it is still the most dynamic subject. In order to cope with global economic competition, governments have made adjustments to their own education policies. This is one of the most important ways in which globalization has affected higher education in all countries.

Vaira's chart provides a clearer picture of the ways and paths in which globalization has affected higher education organizations. This is shown in Figure 2.

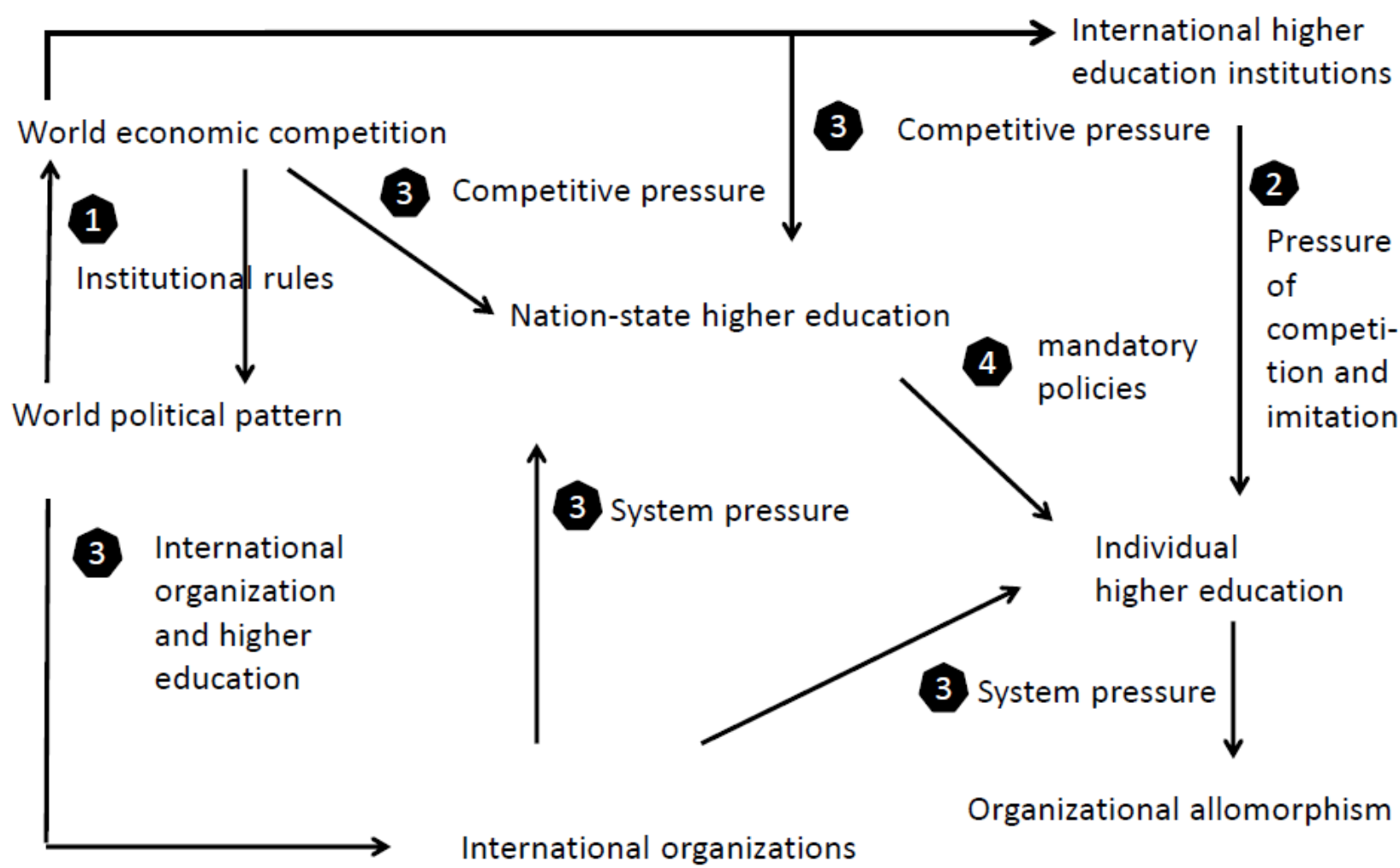

Figure 2. Ways and paths in which globalization has affected higher education organizations

Vaira originally intended to use this chart to show that under the pressure of globalization, higher education institutions in various countries are increasingly becoming "homogeneous allomorphism" in terms of organizational characteristics. However, his demonstration process just shows the path and way that globalization affects higher education institutions. In Figure 2, the path shown by (1) shows that the world economic pattern and political pattern are two mirror combinations that influence each other. The path (2) shows that global economic competition will have a direct impact on the higher education system, such as making universities deeply involved in the economic production process, and putting forward new requirements for the types and modes of talent cultivation of universities. Some well-known universities themselves are international and have international influences. Together with industry associations, they become the media institutions to spread new ideas and practices of higher education. So, within higher education, there is also a global trend, which is amplified and reinforced by trade associations and the mobility of academic staff. This communication brings the pressure of imitation and convergence to individual 
colleges and universities. Another influence context is shown in path (3), in which nation states, as a powerful and principal part of an action in the global economic competition, will make certain adjustments to the country's higher education system for the sake of strengthening their own competitive force or restrained by the rules of the international organizations (such as the rules of WTO require its members to open higher education markets). Such adjustment will become the most direct and powerful pointer for individual universities to act in the form of policies (shown by path (4)). This approach is the most obvious and powerful. Finally, on the basis of the above, individual universities also need to coordinate their specific micro living environment.

\subsection{Globalization brings About the Pluralistic Center World}

Globalization has also had a profound impact on nation states. Globalization breaks down the boundaries of the former nation-state and reconstructs its living environment. In the context of globalization, the activity of supranational organizations (such as OECD, MIF, etc.) and sub-national organizations (such as enterprises, individuals and other individual actors) has restricted the authoritarianism of nation states in many traditional public spheres. The former "government-centric world" has become a "multi-centric world" dominated by governments, transnational and trans-regional organizations, companies or movers. Therefore, for nation states, globalization reconstructs the multiple competitive relations including the above subjects, which brings internal and external tension. This gives rise to the upward and inward diffusion of national authority. Globalization indicates the rise of global civil society and consumerism, and the traditional authoritarianism of nation states is challenged, which makes them unable to take care of traditional social welfare, such as education and medical care.

\subsection{Characteristics of Global Convergence: The Adjustment of the Role of the State and the Introduction of Quasi-Market Mechanisms}

It is the close global linkage that makes the higher education reform of various countries show certain convergence and similarity, and mutual imitation and reference become a symbol of the world higher education reform. But convergence and divergence, as noted above, happen at the same time. Higher education reform in each country has its specific context, so there may be a very unique substance beneath the superficial convergence. Here we will first state how the "identity" is, in short, the adjustment of the role of the state and the introduction of quasi-market mechanism.

Under the impact of globalization, the government of a nation state is forced to become a global-competition state, and has to restructure and reposition its role. In the face of the growing demand for higher education and the declining authoritarian and financial capacity of the government, the new Right ideology took the dominant position in the 1980s and 1990s, and its emphasis on market rules had a significant impact on the relationship between education and the state. In a deregulated environment, centralization has shifted to the direction of devolution and consumerism, and the quasi-market mechanism has been introduced into the field of higher education. Similar to the changes in many other public sectors, the government has changed its traditional role as a service provider and is committed to launching and guiding market and private forces to participate in the provision of various social welfare activities, including education. Its own role gradually changed to coordinator, regulator and quality controller of social activities.

A series of reforms since the 1980s have shown an attempt to restructure the relationship between government, universities and students (consumers). Higher education in the OECD and many countries outside it has been affected to varying degrees by market forces. At the same time, the traditional relationship between the state and higher education has also undergone major changes. "More market, less government" and "more autonomy for colleges and universities to better respond to consumer demand" have become a common demand in higher education reform According to Clark's triangle tension model (state authority, market power and academic power), the power of government and market have changed in the field of higher education.

\section{Marketization and Higher Education Institutions}

The marketisation of higher education has made higher education institutions more and more like "hybrid organisations". In the practice of higher education, institutions of higher learning not only engage in traditional teaching and research, but also carry out a variety of contract education and research projects to increase the school income. In the words of Van Twist \& In't Veld, "it is an entity that operates between the public and private sectors, performs public duties and engages in various commercial market activities". It became a hybrid of a government agency and a commercial enterprise, with both positive and negative characteristics inherent in it. On the one hand, it was seen as a more consumer-oriented, effective and innovative organization. On the other hand, it tends to develop in a negative direction, causing some social and educational problems. The two experts made a special analysis of 
this and summarized the advantages of hybrid institutions as follows: (1) they are better run because they have to compete with other institutions; (2) In order to make the school more characteristic, willing to carry out new reform and development; (3) Pay attention to internal coordination, make it more market-oriented, pay attention to efficiency; (4) With regard to the relationship with the administrators, the company has a more enterprise attitude and will make more efforts to improve the efficiency of the production process and the quality of products; (5) To complete public tasks with less cost and increase additional income; (6) To meet market requirements through business activities; (7) Can improve the enthusiasm and income of the staff.

The disadvantages of mixed institutions are: (1) unfair competition. Colleges and universities will invest some public funds or resources in the process of engaging in commercial activities, so that their products or services are far lower than the market price. At the same time, this unfairness in competition is also reflected in that their commercial activities do not have to pay taxes. (2) Undermining the performance of public responsibilities. Marketing activities can bring great economic benefits to the faculty, but also cause them to neglect the achievement of public higher education goals. Moreover, academic autonomy and professional integrity are compromised when full-time teaching and research staff work on the principle of serving the highest bidder. (3) Wealthy clients will benefit more from hybrid institutions. (4) The government takes on the unpredictable risks that come with doing business, making taxpayers liable to pay for those losses. (5) The responsibility system of a mixed organization tends to be unstable, and the responsibility is no longer directed primarily to the founder, but to the development of numerous customer relationships.

The government has only two options for the negative and problems of this mixed institution: one is to ban it; the second is to use legislation to regulate. Van Twist et al. advocated the second option and proposed the corresponding constraints. The conditions concerning the public domain of universities include: public tasks teaching and research shall not be harmed; students should not be the victims of business activities; the reputation of the university as a public utility must not be damaged; there should be some internal connection between the business activities of the university and its main task. Conditions regarding the private sector of universities include: not allowing unfair competition with private enterprises; the nature and proportion of commercial activities should be clearly defined; business risks should not be passed on to taxpayers. The responsibilities of a university include: accountability to public tasks; responsible for commercial activities; it can regulate the commercial activities and public tasks of the university.

\section{Marketization of Higher Education and Students}

Marketization makes college students become a big consumer or spender. In the past, the government covered most of the cost of education, and students paid a small fee or free tuition. Marketization not only requires students to pay tuition fees, but also gradually increases tuition fees. Many governments require students to pay more for education and training. The popularization of higher education not only leads to a large increase in the demand for higher education funds, but also creates a growing source of income. In the Netherlands, Poland, Russia and Britain, tuition fees are becoming an important source of higher education income, and student aid is being replaced by student loans of all kinds. Austria, France, Portugal and several central European countries are discussing introducing or increasing tuition fees in public higher education.

Under the condition of marketization, the relationship between colleges and students has increasingly become that of "service provider and consumer". Colleges and universities are increasingly dependent on consumers -- students -not only in terms of collecting and raising tuition fees, but also in terms of the government's financial input into colleges and universities. Many governments have changed their education funding system from an "input system", which was based on the number of students enrolled, to an "output input system", which was based not only on the number of students enrolled, There is also a greater emphasis on performance and achievement (graduation rates, etc.) in school. As a result, higher education resources are increasingly dependent on students and their performance. As Watson says, since students can use their feet to decide where to go to college, they have indirect financial distribution. Marketization requires colleges and universities to adjust the policies that only focus on government requirements in the past and create various conditions to pay attention to and meet students' various needs.

According to LeGrand \& Bartlett, there are four criteria for marketization of higher education: (1) efficiency, public services should create economic value; (2) Choice, consumers can choose the quantity and quality of services; (3) Responsibility: universities should consider the needs of shareholders such as students, enterprises and governments; (4) Equality. The provision of education services should be based on need and not influenced by factors such as income, socioeconomic status and age. As far as students are concerned, the latter two criteria are most relevant. Since the funding of institutions of higher learning depends directly or indirectly on students and their performance, 
institutions of higher learning need to be responsive to student needs and develop strategies to successfully recruit more students and deliver high-quality education services. From this argument, providing students with information about the quality of professional education is an important factor in a university's development strategy. At the same time, information about the quality of higher education is also important for the government. But in many national college systems, information about the price, cost, and quality of a major is difficult or limited. In this way, students can only rely on the academic reputation and status of the university and the diplomas awarded by the government. Only a few countries, such as France, the Netherlands and The United Kingdom, have begun to overcome these information markets by publishing data on schools, such as graduation rates, length of schooling, service quality and employment rates, in popular publications. However, Dill points out that even in the United States, where the market system is developed, tuition does not always guarantee that colleges provide satisfactory market information about their specialized teaching. Still, as colleges and universities rely more and more on student contributions, they will become more attuned to student needs and try to persuade (potential) students to choose them over many colleges. In this way, the student-centered theory has a new significance.

\section{The Transformation of Accounting System in Colleges and Universities}

Universities, as mixed institutions, have responsibilities for public services as well as business activities, and that responsibility cannot be separated from computing or accounting. In the West, there are accounting systems in place for non-profit institutions, mixed institutions and enterprises. That is to say, different types of institutions should adopt different accounting systems. With the transformation of higher education institutions, their accounting system should also be changed. Here we will discuss the accounting system of non-profit organizations and enterprises first, and finally discuss the accounting system of colleges and universities.

The accounting system of non-profit organizations such as churches and charities is designed to ensure that their activities are strictly consistent with the requirements and restrictions of the law, other organizations or individual donors. At the same time, this non - profit accounting system has considerable limitations, to absolutely meet the external requirements. In contrast to commercial enterprises, non-profit organizations have no concept of profit and investment. They are dedicated to the creation of value, but that creation is not entirely reflected in money. As a result, the existence of non-profit organizations is largely dependent on budgets (grants, donations) rather than market revenue. This dependence on the budget affects its accounting system. Therefore, the accounting system of non-profit organizations is called "fund accounting system", which is very restrictive and its resources can only be used for the goals, projects and tasks prescribed by the governing organization.

Business accounting systems are used to create value through market exchange. For enterprises, accounting system is a tool to manage an organization. It can be measured by money, including cost, revenue, turnover, investment, assets, debt and other factors, reflecting the business behavior of an enterprise. In this system, the comparison of income and expenditure is an important part of the value creation process. It is precisely this value-creating characteristic of enterprises that produces a variety of business accounting fields, such as financial accounting, cost accounting, and operating accounting. Unlike non-profit organisations, the survival of businesses depends on profits and attractiveness as an investment option. This dependence, in turn, gave rise to a system called "proliferative basic accounting".

A notable feature of marketization is the shift from input financing to output - and price-based financing, which is manifested by direct allocation to suppliers, to dependence on the sales of the services they provide and their attractiveness to funding. In a competitive environment, this shift directs management toward customer satisfaction.

Marketization has also brought about significant changes in the nature and function of the balance of income and expenditure of higher education institutions. High tuition fees and contracts for teaching and research have greatly increased the income of universities. However, there is a problem of loss and cost in teaching and researching contracts, which requires the introduction of cost accounting principles. Project budgeting is an appropriate accounting method, widely used in European universities. Adding basic accounting to higher education institutions can boost staff motivation, but Wasch sees many problems. First, the university is a mixed institution of public responsibility and commercial activities, which cannot be fully applied to the proliferation of basic accounting system, because public responsibility cannot be measured by money. Second, most of the income of colleges and universities is brought by non-market factors, namely the government budget, which makes the comparison between income and expenditure very unreal and meaningless. Under this system, universities have no fear of bankruptcy, so the impetus and incentives from the market are curtailing. Still, Voss believes the hybrid institution should adopt business tools such as cost accounting and flexible budgeting, cost standards, and job measurement techniques to improve efficiency. 
The marketization of European higher education is not so much an imitation of American higher education model as a new measure and attempt to solve the heavy burden of government-run higher education and improve the efficiency of running schools. Reflected in the theoretical research, European education experts reached the following consensus in the debate: the marketization of higher education is not absolute privatization, but the introduction of market mechanism into higher education; Higher education market can only be called a quasi-market, not a complete market; Under the condition of marketization, higher education institution is a kind of mixed institution, which has advantages and disadvantages. The importance of students in the minds of higher education organizers has increased and become an important basis for higher education funding and decision-making. Finally, marketized colleges and universities need a suitable accounting system as a powerful guarantee to improve the efficiency of running schools.

\section{Conclusions}

Marketization of higher education has its benefits, but it also has its worries. Faced with this dilemma, can we choose to retreat? Throughout the development process of higher education marketization, there are many practical contradictions and difficulties, but the marketization of higher education has been a national general direction, supported by international organizations and laws and regulations. From a realistic point of view, what universities gain is also the material basis of their own existence, and practice has proved that the market mechanism has incomparable advantages over the traditional university operation mode.

In the final analysis, the government should strengthen its responsibility, play a role of its management and supervision of higher education and further standardize the competition mechanism to eliminate the disadvantages of marketization. It is necessary to comprehensively deepen reform of the new historical starting point, adhere to the market-oriented reform direction of higher education and crack hinders the system obstacle of marketization of higher education reform and management to better adapt to the rules of the development of market economy. To improve the quality of higher education and the level of running schools, the government should train high-quality talents to meet the requirements of the development of market economy, and promote the confluence development of higher education.

\section{References}

Barrell, B. (1999). Technology and Change in Atlantic Canada's New Secondary English Language Arts Curriculum. English Education, 31(3), 231-247.

Bartelson, J. (2000). Three Concepts of Globalization. International Sociology, 15(2), 180-196. https://doi.org/10.1177/0268580900015002003

Baylis, J., \& Smith, S. (Eds.) (2001). The Globalization of World Politics: An Introduction to international relations (2nd ed.). New York, NY: Oxford University Press.

Bourguignon, F. (2015). The Globalization of Inequality. Princeton: Princeton University Press.

Brodie, J. (Ed.) (2002). Critical Concepts: An introduction to politics (2nd ed.). Scarborough, ON: Prentice-Hall Canada.

Castells, M. (2000). The rise of the network society (2nd ed.). Oxford: Blackwell.

Dale, R. (1997). The state and the governance of education: An analysis of the restructuring of the state-education relationship. In A. H. Halsey, H. Lauder, P. Brown, \& A. S. Wells (Eds.), Education: Culture, economy, and society (pp. 273-282). Oxford.: Oxford University Press.

Deem, R. (2001). Globalisation, new managerialism, academic capitalism and entrepreneurialism in universities: Is the local dimension still important?. Comparative Education, 37(1), 7-20. https://doi.org/10.1080/03050060020020408

Dill, D., \& Sporn, B. (1995). The implications of a post-industrial environment for the university: an introduction. Tarrytown. NY: Elsevier Science IAU Press.

Edelman, M. (2001). Social Movements: Changing paradigms and forms of politics. Annual Review of Anthropology, 30, 285-317. https://doi.org/10.1146/annurev.anthro.30.1.285

Fletcher, J. F., \& Stren, R. E. (1989). Language Skills and Adaptation: A Study of foreign students in a Canadian university. Curriculum Inquiry, 19(3), 293-308. https://doi.org/10.1080/03626784.1989.11075332

Francis, N., \& Ryan, P. M. (1998). English as an International Language of Prestige: Conflicting cultural perspectives and shifting ethnolinguistic loyalties. Anthropology \& Education Quarterly, 29(1), 25-43. 
https://doi.org/10.1525/aeq.1998.29.1.25

Frempong, G., Ma, X., \& Mensah, J. (2012). Access to Postsecondary Education: Can schools compensate for socioeconomic disadvantage?. Higher Education, 63, 19-32. https://doi.org/10.1007/s10734-011-9422-2

Fuss-Kirkwood, T. (2001). Our Global Age Requires Global Education: Clarifying definitional ambiguities. The Social Studies, 92(1), 10-15. https://doi.org/10.1080/00377990109603969

Green, A. (1997). Education, globalization, and the nation state. London: Macmillan. https://doi.org/10.1057/9780230371132

Kaiser, F. R. J., Florax, J. B., Koelman, et al.. (1992). Public Expenditure on Higher Education. London: Jessica Kingsley Publishers.

Kieffer, M. J., \& Lesaux, N. K. (2009). Accommodations for English Language Learners Taking Large-Scale Assessments: A meta-analysis on effectiveness and validity. Review of Educational Research, 79(3), 1168-1201. https://doi.org/10.3102/0034654309332490

Kiely, R. (2007). The New Political Economy of Development: Globalization, imperialism, hegemony. New York, NY: Palgrave Macmillan.

Kirby, D. (2007). Reviewing Canadian Post-Secondary Education: Post-secondary education policy in post-industrial Canada. Canadian Journal of Educational Administration and Policy, 65, 1-24.

Lam, Y. Y. (2010). Impact of Globalization on Higher Education: An empirical study of Education policy \& planning of design education in Hong Kong. International Education Studies, 3(4), 73-85. https://doi.org/10.5539/ies.v3n4p73

Larsson, T. (2001). The Race To The Top: The real story of globalization. Washington, DC: The CATO Institute.

Le Roux, J. (2001, May). Re-Examining Global Education's Relevance Beyond 2000. Research in Education, (65), 70-80. https://doi.org/10.7227/RIE.65.6

Marginson, S., \& Rhoades, G. (2002). Beyond national states, markets, and systems of higher education: A glonacal agency heuristic. Higher Education, (43), 281-309. https://doi.org/10.1023/A:1014699605875

Neave, G., \& Van V. (1991). Conclusion. In Neave, G., \& Van Vught (Ed.), Prometheus Bound. Oxford: Pergamon Press.

Olds, K., \& Robertson, S. (2014). Globalizing Higher Education and Research for the 'Knowledge Economy'. MOOC: University of Wisconsin-Madison, \& University of Bristol.

Orr, D. (2005). Can performance-based funding and quality assurance solve the state vs market conundrum?. Higher Education Policy, 18, 31-50. https://doi.org/10.1057/palgrave.hep.8300071

Resnik, J. (2009). Multicultural Education - Good For Business But Not For The State? - The IB curriculum and global capitalism. British Journal of Educational Studies, 57(3), 217-244. https://doi.org/10.1111/j.1467-8527.2009.00440.x

Ritzer, G. (Ed.). (2007). Blackwell Companion to Globalization. Oxford: Blackwell. https://doi.org/10.1002/9780470691939

Rodrik, D. (2011). The Globalization Paradox: Democracy and the future of the world economy. New York: W. W. Norton \& Company. https://doi.org/10.1355/ae28-3k

Rootes, C. A. (1990). Theory of Social Movements: Theory for social movements. Philosophy and Social Action, 16(4), 5-17.

Sassen, S. (1998). Globalization and Its Discontents: Essays on the new mobility of people and money. New York, NY: The New Press.

Scholte, J. A. (2005). Globalization: A critical introduction (2nd ed.). Great Britain: Palgrave Macmillan. https://doi.org/10.1007/978-0-230-21207-7

Scott, A. (1990). New Social Movements-Major Themes, Chapter 1. In Ideology and New Social Movements (pp. 13-35). London, UK: Unwin Hyman.

Slaughter, S., \& Leslie, L. L. (1997). Academic capitalism. Baltimore: Johns Hopkins University Press.

Slaughter, S., \& Rhoades, G. (2004). Academic capitalism and the new economy: Markets, state, and higher 
education. Baltimore: Johns Hopkins University Press.

Vaira, M. (2004). Globalization and higher education organizational change: A framework for analysis. Higher Education, (48), 483-510. https://doi.org/10.1023/B:HIGH.0000046711.31908.e5

Van, T., \& In't V. Public organizations in the market place. Risks, profit opportunities and conditions for existence. NIG Working Papers, 99(5).

Williams, L. G. (1995). The "marketization" of higher education: Reforms and potential reforms in higher education finance. In D. D. Dill \& B. Sporn (Eds.), Emerging patterns of social demand and university reform: Through a glass darkly (pp. 170-193). Pergamon: IAU Press.

\section{Copyrights}

Copyright for this article is retained by the author(s), with first publication rights granted to the journal.

This is an open-access article distributed under the terms and conditions of the Creative Commons Attribution license (http://creativecommons.org/licenses/by/4.0/). 